\title{
Tercentenary of Samuel Pepys
}

\section{By T. E. JaMES}

$\mathrm{T}$ HE three hundredth anniversary of the birth of Samuel Pepys, a moving, dramatic figure in the political and social annals of the Restoration period, falls on February 23. Born either at Brampton, near Huntingdon, or in London (so records say), he was educated at St. Paul's and Magdalene College, Cambridge, graduating there in 1660. In 1655, Pepys married and had, for some time, to face comparative poverty. He was favoured, however, with the patronage of Sir Edward Montagu, and was employed as secretary to the expedition for bringing Charles II from Holland; this leading to permanent and official employment at the Admiralty. In 1679 Pepys was committed to the Tower on a State charge, but was incontinently released.

Pepys's "Diary" was begun on January 1,1659-60. It was written in great secrecy. The final entry was made on May 31, 1669. "The "Diary" itself was not published until 1825. Therein, the high intent, the ignoble, and the frailties of Pepys's own life resolve into an inexplicable, baffing display of inwardness.

Not the least monument to Pepys, where memory is deep and lasting, was the bequest of his library and MSS. collections (by preference) to Magdalene College, Cambridge. An excellent general account of the Pepysian Library has been given by $\mathrm{H}$. B. Wheatley (1880).

During the early part of Charles II's reign, the Royal Mathematical School of Christ's Hospital, still part of the major foundation, was established. Pepys, as a governor, took a lively interest in its efficient administration. On February 15, 166l-2, Pepys was made a younger brother of the Trinity House and in 1676, Master of the Trinity House. He was elected Master of the Clothworkers' Company in 1677 .

Readers of NATURE will be more particularly interested in the association of Samuel Pepys with the Royal Society of London in its early days, particularly with those men who had been most active in its institution. In course of time we witness Pepys's own inclusion in the organisation; ultimately, his assumption of the office of president.

We need entertain no doubt that Pepys was cognisant of the various steps that were taken to establish the Society. He had friends of quality, who would relate what had happened, whilst Pepys himself, Clerk of the Acts (Navy), was favoured in the Restoration Court circle, where news spread apace. Hence, on January 9, 1664-5, Pepys is able to record that the Royal Society's charter book had been brought to Whitehall, and that the founder's signature and that of the Duke of York were duly inscribed. Indeed, he had not long to wait for acceptance amongst the philosophers. On February 8, 1664-5, "Samuel Pepys, Esq., was proposed candidate by Mr. Povey", the business prior to this being the election of Edward, Earl of Clarendon, the famous Lord Chancellor. Mr. Pepys found himself in excellent company. Thomas Povey, it may be mentioned, was an original fellow. He had mechanical gifts and for many years proved serviceable to the Society. Evelyn considered him to be "a nice contriver of all elegancies".

On February 15, 1664-5, Pepys was duly elected, signing the charter roll then and there. Going home, Pepys recorded his experience thus :-

"With Creed to Gresham College, where I had been by Mr. Povy; and the last week proposed to be admitted a Member, and was this day admitted, by signing a book and being taken by the hand by the President . . . and some words of admittance said to me. But it is a most acceptable thing to hear their discuurse, and see their experiments. After this being done they to the Crowne Taverne, behind the 'Change, and there my Lord and most of the company to a club supper; . . Above all, Mr. Boyle to-day was at the meeting, and above him Mr. Hooke, who is the most, and promises the least, of any man in the world that ever I saw."

Pepys chronicles, as also amongst the company, Sir Paul Neile, Sir Robert Moray, Dr. Clarke, Dr. Whistler, and Dr. Goddard. On March 1, follow. ing, the subjoined entry occurs :-

"At noon I to dinner at Trinity House*, and thence to Gresham College, where Mr. Hooke read a second very curious lecture about the late Comett ; among other things proving very probably that this is the very same Comett that appeared before in the year 1618 , and that in such a time probably it will appear again, which is a very now opinion. . . Then to the meeting. . . ."

In the following week (March 8), Pepys goes to the weekly meeting as a fellow. A letter was read from Huyghens to Sir R. Moray, containing first his desire to be more particularly informed about the pendulum watches committed to Major [later Sir Robert] Holmes. Mention was thereupon made of Holmes's relation of the performances of pendulum watches on his voyage to Guinea, and doubts were cast. Accordingly, Mr. Pepys was asked to inquire into the matter for the satisfaction of the Society. On March 15, Pepys gave an account of information that he had obtained from the master of the Jersey ship who had sailed with Holmes on the Guinea voyage. Something additional devolved on Pepys. He was desired to bespeak a man at Deptford for diving. The diver was to be sent to Robert Hooke to be instructed by him concerning the use of "air-boxes" under water. Later, in May, Lord Brouncker reminded

* The Navy Office, where Pepys resided, lay between Crutched Friars and Seething Lane, by the Tower.

$\dagger$ See in this connexion, NATURE, Feb. 7,1884, p. 345 , article in "Our Astronomical Column". 
Pepys of this commission, as the season was favourable. On March 22, the subject of Holmes's watches arose, and Pepys was requested to procure the journals of those masters of ships who had been with Holmes in Guinea and differed from him.

The incidence of the Plague and the Great Fire which followed were periods of intensive public anxiety and apprehension, and we lose contact with the College world for some time. But on November 14, 1666, Pepys records that Dr. Croone had told him that at that night's meeting, "which, it seems, they now have every Wednesday again", there were experiments on blood transfusion. A year later (November 21, 1667), there is another reference:-

. . "I to the office, where did much business till after candlelight, and then my eyes beginning to fail me, I out and took coach to Arundell House, where the meeting of Gresham College was broke up ; but there meeting Creed, I with him to the taverne in St. Clement's Churchyard."

On November 30, 1667, Pepys tells us that he went to Arundel House to the election of officers of the Royal Society for the next year; that he was near being chosen, but glad that he was not, for he could not have attended, but took it as a mighty respect to have been named. Also, that the company was great, the elections long.

On April 2, 1668, Pepys mentions a visit to the Royal Society, with Lord Brouncker, and of being "forced to subscribe" to the building of a College; and that he "did give forty pounds". Pepys held views adverse to the scheme, and these may have reflected themselves in a partial withdrawal of interest, for not until November 30, 1674, do we again pick up the threads of association with the Society. But it is with enhanced prestige. At the anniversary meeting, Mr. Pepys is among ten new members chosen for the council. His ally, Sir Joseph Williamson (P.R.S., 1677), was also of the number. Pepys attended the meeting on December 3, when a resolution was taken that every member of council should provide an experimental discourse for the Society, to be made within the year, either by himself or by some other member of the Society; or, "to pay forty shillings". Pepys promised a discourse.

On December 17, Pepys is placed upon a committee to consider how Dr. Wilkins's legacy of $\mathfrak{1 4 0 0}$ might be laid out. Also, he was joined with Sir R. Southwell and the president in an applica. tion to Prince Rupert "concerning the mischief which his glass-house does to Chelsea College". In January ensuing the president announced his discourse. Mr. Pepys, he said, had offered to make his the next week after his own; it does not appear, however, that Pepys held to his offer.

On February 18, 1674-5, "Mr. Isaac Newton" was admitted a fellow. Since Pepys was a member of council, there is a presumption that he was present on this particular occasion. Pepys was irregular in his attendances, however, during the year, and he was not continued on the council. But his light was only temporarily dimmed, for on November 30,1676 , he re-appears as one of ten new members, and among these were Sir Christopher Wren and John Evelyn. Again Pepys served twelve months.

In the politically stormy year of 1680, "far away at Newmarket, Pepys was taking down, at the dictation of his sovereign, the tale of that miraculous escape from Worcester of twenty-nine autumns before" (Bryant).

We now pass to the year 1681, when Pepys re-appears in the Royal Society. At the anniversary meeting on November 30 , he enters the council, and with him, Evelyn and Flamsteed; Sir Christopher Wren is president. Hooke was a colleague. Pepys served for one year. Coming to 1684 , at the anniversary meeting on December 1 (St. Andrew's Day falling on a Sunday), Sir John Hoskyns in the chair, Samuel Pepys, chosen for the council, is also elected president of the Society. Notwithstanding that his attendances were infrequent, he was, in 1685 , continued in the presidency for yet another year, this nomination marking the closing and final period in that office.

Here it may be mentioned that at a council on June 2, 1686, the first book of Newton's "Principia" was ordered to be printed. Pepys was not present, nor on June 30 , when it was ordered that the president be desired to license the book. Sir John Hoskyns occupied the chair. Pepys's imprimatur was given on July 5 .

Samuel Pepys was never a very healthy man, and he died at Clapham on May 26, 1703. He was buried in St. Olave's Church, Crutched Friars. His portrait, by Kneller, and his own gift, adorns the apartments of the Royal Society.

\section{Obituary}

Prof. Harlan W. Frsk

$T^{\mathrm{H}}$ E science of terrestrial magnetism has lost an outstanding investigator and the staff of the Carnegie Institution of Washington an esteemed member by the sudden death, on December 26, of Prof. Harlan Wilbur Fisk, chief of the Section of Land Magnetic Survey of the Institution's Depart. ment of Terrestrial Magnetism. During his long period of service with that organisation, extending over more than a quarter-century, he contributed much to the success of the world magnetic survey both by personal participation in the observational work and by planning and supervising the work at repeat-stations for obtaining data where most needed for investigations in his complex field.

Prof. Fisk was born at Geneva, Kansas, on September 25, 1869, but his youth was spent in Minnesota where he received his fundamental scientific training at Carleton College, Northfield. Here his enthusiasm for mathematics and 